\title{
Populism Poses a Threat to International Security
}

\author{
Xinyue Zhai ${ }^{*}$, Youyou $\mathrm{Xu}^{2 *}$ \\ ${ }^{1}$ Xiamen University, Xiamen, China \\ ${ }^{2}$ Shenzhen Middle School, Shenzhen, China \\ Email: zhxy3744@163.com,240025330@qq.com
}

How to cite this paper: Zhai, X. Y., \& Xu, Y. Y. (2020). Populism Poses a Threat to International Security. Open Journal of Political Science, 10, 481-492.

https://doi.org/10.4236/ojps.2020.103029

Received: April 20, 2020

Accepted: July 6, 2020

Published: July 9, 2020

Copyright (C) 2020 by author(s) and Scientific Research Publishing Inc. This work is licensed under the Creative Commons Attribution-NonCommercial International License (CC BY-NC 4.0). http://creativecommons.org/licenses/by-nc/4.0/

\begin{abstract}
The unprecedented economic growth in the 21th century could be largely attributed to a relatively peaceful international order following the collapse of the bipolar world order. However, contemporary populist backlash has threatened the international security, rendering the extant peace more and more fragile. This article aims to evaluate and explain certain threats posed by populism in the west, arguing that the populism, which challenges incumbent democratic regimes, economic globalization trend as well as various international institutions, is a serious threat to international order. A detailed explanation on the impact of populism, as exemplified by prominent leaders like Boris Johnson and Donald Trump, and by political events such as Brexit substantiates the article's claims. In conclusion, the article argues that pan-West populism is on the rise, destabilizing current liberal governments and international institutions. Several policy recommendations are made to tackle the populist threats, such as reforming democratic procedures, implementing moderate redistribution policies, and rebalancing powers between international institutions and individual member countries.
\end{abstract}

\section{Keywords}

Populism, Cultural Backlash, Anti-Globalization

\section{Introduction}

Following Brexit and the electoral victory of Donald Trump, the rise of populism on an international scale has revealed deep-rooted cultural problems and economic division within contemporary western societies. The world is turning away from a collaboration-extensive, highly institutionalized, and peaceful out-

*They are the co-first authors. 
look, which has been pictured at the end of bipolarity. Propelled by nativist sentiments, regional values, and economic dislocation, populist leadership and political conflicts arising from realist interests are becoming increasingly prevalent, posing a substantial threat to international security.

Therefore, what this article aims is to specify the definition of populism, analyze its impacts, and focus on the threats it might pose to the liberal international order. This article also seeks to study the impact of contemporary populism from three different aspects, including its political effects, economic implications, and its influences on international institutions. In this way, this article offers a relatively comprehensive analysis of the populist rise focused its outcomes and its potential threats. It ends with several policy recommendations regarding the threats to international security induced by populism. For the purpose of this article, populism is understood as a specific set of rhetoric and logic reflecting first-order principles about who should rule, claiming that legitimate power rests with "the people" rather than the elites, or the national groups not identified as "the people". The rise of populism in the west poses a serious threat to liberal democracy, destabilizes economic globalization and weakens international institutions.

The first section starts by analyzing the populist rise in Europe and the US, identifying its threat in politics and economics, as well as the threat to international institutions. Politically, populism is a potential threat to liberal democracy since it obstructs democratic functions and generates xenophobic hostility. Economically, populism poses a threat to global economy because populists disrupt economic globalization by reducing economic interdependence, and the hostility in trade disputes may escalate into political conflicts. Regarding international institutions, populists often pay little or no deference to those institutions, hindering global governance and international cooperation.

This second section restates the three kinds of populist threats, and then proceeds to offer policy recommendations to tackle populism. By fixing the democratic regime, making compensation to those who have lost in globalization through redistribution, and reforming the international institutions, the populist appeal may decline over time.

\section{Related Works}

Scholars have studied on this issue extensively; however, extant theories proposed by scholars mostly focused on causes of the populist rise in contemporary western democracies. These theories have offered insightful explanations, but the outcomes of the populist rise-or the threat that populists impose when they have successfully expanded their political influence-is hardly addressed.

Some scholars have quoted economic circumstances as the cause of the rise of populism in the contemporary western society. More specifically, they argued that the economic redistribution effects of globalization have inflamed more extreme nationalist sentiment, therefore encouraging nativist propaganda of con- 
temporary populism. For instance, the theory of globalization, proposed by Dani Rodrik, identifies a significant downside of globalization that can potentially trigger anti-globalization populist sentiment: the ratio of welfare state spending (a greater amount of which indicate a greater degree of economic inequality) increases as trade is further liberalized. In other words, he argued that as economic globalization is further achieved, it will result in increasing inequality, whereas relatively trivial economic gains is achieved in comparison to a great increase in income inequality, which leads to political dissatisfaction and give rise to populism. Dani Rodrick thus proposes a policy recommendation on increasing welfare state to address public perception of economic inequality (Rodrik, 2018). Rodrik's theory, however, is predominantly centered on economic performance as a source of political discontent and incentive for populist rise. The popular perception of elitist politics and polarized party systems are also political factors that could lead to political discontent, as people feel themselves underrepresented and elected officials unaccountable. This article aims to deal with such political incentives of populist rise in western democracies.

Other scholars like Pippa Norris and Ronald Inglehart have also proposed the theory of populist cultural backlash. They maintained that a trend of cultural backlash explains the change of voting behaviors and turnouts in western liberal democracies, shifting from liberal-minded, bureaucratic politicians to populist leaders. The cultural backlash theory suggests that although economic reasons remain valid in modern society, the main reason for the rise of populism is the cultural reaction, fostered by entrenched political culture of authoritarianism and extremism, against the prominence of post-Cold War neoliberal values, which began to gain popularity in 1980s (Norris \& Ingleheart, 2016). Their analysis of voting behavior concludes that the tide of populism will continue even if the globalization is rebalanced. This theory of cultural backlash predicated on illiberal political culture does not pertain to all western societies, however. Obviously, countries like UK or America without an entrenched political history of anti-liberalism, which are much unlike countries like Austria or Hungary, still have seen rise of populism embodied in the electoral victory of Donald Trump. Therefore, what this article aims is to provide an analysis of populist rise in contemporary western democracies centered on liberal democratic countries like UK and America, where populism seemed unlike to develop at first glance, but actually found its greatest appeals and electoral success.

Besides the aforementioned two issues about extant literature, scholars have also offered various definitions of populism, leading to divergent results, especially for scholars analyzing the causes of populism. On one hand, scholars citing globalization as the main reason for the populist rise tend to include both left-wing and right-wing populists in their analysis. For instance, Dani Rodrik claims that are two kinds populism matching two social cleavages, an ethno-national/cultural cleavage and an income/social class cleavage. He holds that in Europe, right-wing populism is the most prominent due to the salience of 
immigration in the everyday life of voters. In Latin America, left-wing populism is more prevalent because of the anger against the domestic group who supported the entry of foreign companies and capitals. The U.S. is a more complicated case which combines characteristics of both of these paths (Rodrik, 2018). Although this theory offers great insights into the economic complication of anti-globalization populists, it fails to take into consideration the authoritarian tendencies of populist leaders as well as their supporters, and their disdain for most international institutions, some of which have nothing to do with liberalized trade.

On the other hand, scholars citing the cultural backlash (Noris \& Ingelheart, 2016) or representation gap (Oliver \& Rahn, 2016) as the main reasons do not consider left-wing politicians who appeal to "the people" as populists. According to Ronald Inglehart and Pippa Norris, populism can be defined as the political success of the leaders or parties which claim to represent "the people", with authoritarian leaning and favoring direct forms of democracy, while demonstrating nativist tendency (Norris \& Ingelheart, 2016). Left-leaning politicians who are not a part of mainstream establishment can hardly fit this description, since they are usually more supportive of the "cosmopolitan liberal values", contrary to the aforementioned definition of populists. Similarly, J. Eric Oliver and Wendy M. Rahn, who claim the representation gap to be the primary cause of populist rise in the U.S., have named three specific traits of populist rhetoric. The listed elements, including anti-establishment, creation of a unified people, and simplicity of language, all point to right-wing populists rather than left-wing ones (Oliver \& Rahn, 2016).

It's evident that the varying definitions have inevitably led to different conclusions about the cause of populism, since scholars have focused on different aspects on populist rise. This divergence in definitions suggests that the root of populism is still somewhat unclear.

In summary of the extant literature on populism, which focuses mainly on the causes of the populist rise in western democracies, and employs a diverse range of definitions, have left much space for improvement and additional discussions. The varying analysis on the outcomes of populist leaders or parties in power-or to say, the specific and immediate threats that the populist rise imposes on the liberal international order-is in urgent need.

\section{Populist Threat to International Security}

Populism is an international threat to liberal democratic institutions, the liberalized trade, and global governance.

\subsection{Populist Threat in Politics}

1) Prevailing public distrust of elitism has given rise to populist leaders who strategically appealed to the people. These leaders threatened liberal democracy by thwarting government functions, maneuvering the regime for their own gains, and aggravating the trend of populist backlash. 
A prominent example featured Boris Johnson, the present UK prime minister. Since Boris's ascendancy into government, he has claimed that an "elitist conspiracy thwarted Brexit" (Penny \& Hutton, 2019). In the name of the "people" to counter that conspiracy, he unconstitutionally prorogated the parliament until 17 days before the scheduled departure from the EU in order to evade parliamentary scrutiny of his own plans for Brexit, and also passed his plans in the Conservative majority parliament after the 2019 election. Although it's far-fetched and irrational to view Commons as entirely "elite-maneuvered" and unrepresentative of people's wills, Boris's strategy of boldly discrediting and suspending the Commons did appeal to the anti-elitist public, winning him even more popularity.

Boris Johnson's case typically illustrated how populist leaders thwarted democratic processes to realize their own policies and to elongate their party's occupation of government. Like Boris, Victor Orban from the populist Fidesz Party of Hungary, has even issued a constitution that perpetuated his stay in government (Müller, 2016). Other populist parties also have pursued a similar end, like True Finns and Freedom Party of Austria. Thus, in a way, Boris's case of strategically encroaching the government while appealing to the public also aggravated if not foreshadowed, a pan-European populist attempt to attack elitism and alter incumbent democratic procedures or institutions.

This has broader implications for the impact of populism around the globe. Currently, as no effective mechanism exists to check the rise of populist leaders like Boris, it poses a significant threat on the future of worldwide liberal democracies.

2) Populists employ targeted, potentially chauvinistic or xenophobic propaganda to appeal to "the people", resulting in populist occupations of government, and subsequently, more aggressive international policies.

Boris's attacks on elitism in the British parliament successfully empathizes with most British people, especially the economic have-nots and politically-neglected people with low income and underdeveloped regions. Despite abundant reports of racism and Islamophobia, Boris was still widely respected as someone with "immense charisma, wit, sex appeal and celebrity gold dust," (Gimson, 2015) or at least, unlike Westminster elites who were distant from the "people".

These populist strategies to appeal to his "people" at expense of social minority groups and upper-class elites worked in his favor in the 2019 general elections, securing his ministry in the government. Subsequently, Britain is now turning to a more nativist and isolationist orientation, exacerbating its relations with the continent. It's unclear whether he would join forces with other continental populist forces or not (Taggart, 2004), yet he certainly facilitates, if not initiates, the populist push for nativism, xenophobia and hardline political sovereignty, or even political turmoil in Europe.

Similarly, US president Donald Trump also employed a nativist agenda with politically charged "blame language" (Oliver \& Rahn, 2016). He incited public 
discontent and fear towards those who are not identified as "the people"-social minorities or "non-Americans" (Moffitt, 2015). On one hand, his rhetoric of fear relies on counterfeit data. Although candidates and politicians could, and they sometimes do, make mistakes on facts in their public speeches, Trump was evidently far less focused on fact-checking, yet he was simultaneously far more successful at fomenting insecurity. Even in the rather unlikely occasion when his claims are factually accurate, his rhetoric is always provocative and divisive. In either case, the populist style of political communication leads to more hostility, neuroticism and fear inside the nation. For instance, the mysterious death of Qasem Soleimani was at least partly an attempt to support his re-election, taking advantage of the nationalistic and xenophobic tendencies of his base. This aggressive move has in turn ignited the first spark of Islamophobic hostility during Trump's presidency, threatening domestic social order and deteriorating international relations with Iran. To some extent, populists such as Donald Trump contribute to producing the very crises to which they claim to respond (Brubaker, 2017).

The well-devised propaganda of Boris's and Trump's both led to internal and external xenophobic hostility. Although this tension has remained largely on a rhetorical level, populists have succeeded in directing public discontent at those who don't belong to the "people". They have made up justification for the public with their populist claims, if they were to escalate that tension into a physical conflict. The following section will turn to the economic implications of the populist rise.

\subsection{Populist Threat in Economics}

1) Populists are exceedingly hostile towards liberalized trade both regionally and globally. They might reduce economic interdependence, and eventually disrupt global economy if they come into power.

The EU has long been berated by populists on grounds of undue institutionalization and inefficacy, especially when confronting economic crises. Reflecting a broader populist, anti-institutionalization trend, Brexit certainly strengthens populists' criticism of the EU. However, while Britain is now free from EU restrictions, it arguably generates more threats to the British economy, or worse, the entire EU economy system at large. The impact of Brexit would hurt the mutual economy of Britain, as Britain lost its biggest trading partner. Other more immediate consequences include depletion of medicines and transport meltdown on borderlines. In the long run, it also implies a massive retreat of net foreign investments and a severe decline in income level. For EU, it lost its second-largest budget contributor, and its member states are sure to experience adverse reactions. EU would also confront even more intimidating threats from populists, who have long resented the elitist design of a highly interdependent, strictly institutionalized euro-based economy. These populists, motivated by Brexit, would seek more economic discretionary powers from EU for their own country. In a word, Brexit would potentially pose a prolonged economic threat 
to various countries on an international scale.

To summarize, the profound consequences of Brexit exemplified how populism disrupts the economy regionally and globally. At a time of globalization, the potential widespread economic disarray might pose a long-term threat to international security.

2) Populists adopt protectionist policies that may harm the economic interests of other countries, inducing potential political conflicts and threatening the international order.

Again, Boris Johnson's ministry exemplifies this case. His uncompromising stance in securing British sovereignty was reflected in his reluctance to abide to any EU economic principles (Toynbee, 2020). But while he negotiated with EU on trade agreements, he actively sought to build new trade partners, like with the US. This aggrandizes tensions between Britain and continental Europe, challenging the trend of European integration. The elites in EU who originally pushed for that trend would be abashed. Populists, who long resented the increasing democratic deficit in EU, might further push for political disintegration in response to Brexit.

But the Irish border question already exemplifies another more immediate political crisis, as the borderline along Northern Ireland turns into the only land border between UK and EU. A quick glimpse into history spells the chances of setting up physical checkpoints, fortification and military inspection to address the borderline issue. A car bomb in January, 2018 already signaled on possibility of violent conflicts, threatening peace and security on both sides.

Similarly, in the US, Trump adheres to protectionism on global trade. Although the political conflicts are less imminent than the one with Brexit, the potential threat posed by protectionist trade policy must not be overlooked.

The trade war with China, fueled by nationalism, has exacerbated the already belligerent relationship between two governments. Especially during the initial spread of the recent COVID-19 epidemic, while other countries offered considerable help to China, US has still fixed their attention on addressing economic implications for the trade war. In turn, the apathy of Trump's administration has deteriorated the prevalent public opinion in China, rendering the public more radically xenophobic and hostile to the US.

In conclusion, populists tend to view global trade in an oversimplified way, deeming the "people" as the primary losers, and the "elites" and the "outsiders" as winners. They seek to restore justice by taking back what "people" have lost from those who have unfairly gained. With this illusioned zero-sum mindset on economic globalization, there will be greater tension between directly competitive countries. Eventually, the global cooperation might be hindered and the world would be prone to political conflicts. The next section will turn to the populist threat to international institutions.

\subsection{Populist Threat to International Institutions}

Populists pose threats to incumbent international institutions both politically 
and economically. They distrust intragovernmental organizations that foster international trade, or attempt to disrupt certain political goals that those organizations might uphold like combat of climate change and peacekeeping.

Trump best exemplifies this populist ideology of anti-institutionalization. $\mathrm{He}$ has publicly disregarded international institutions or the liberal international order, except when they work for US's best interests. He prominently challenges WTO, along with the international trade laws, with his contemptuous stance. During the trade war with China, both US and China frequently violated WTO's procedural and substantive rules, as they raised tax barriers unilaterally instead of bringing the issue to the Dispute Settlement Body. Resorting to unilateral sanctions, like imposing tariff or quantitative restrictions, rather than international trade laws, the two countries offered a poor example for other countries in similar disputes.

If the importance of international institutions continues to decline due to populist threat, they would fail to act as a mediator of competing countries around the globe. First, with hostile countries facing each other directly, the possibility of escalation to physical conflict is greater, putting the international security at risk. Second, in absence of a multilateral system, the bilateral negotiation favored by populists would be more power-based instead of rule-based, disproportionately favoring great powers. In this case, economically disadvantaged areas would lose greatly and unfairly, engendering nationalism, hostility and possibly extremism. Third, the central function of international institutions, like promoting human rights, combating climate change and peacekeeping, are undermined by the rise of populism. The decline of those international institutions would therefore hinder the collective efforts of humankind to make the world a better place for future generations. The threats that populism poses to the international order should not be overlooked.

\subsection{Summary}

Populism poses a threat to domestic democratic functions, economic globalization, and international institution, challenging the liberal international order. First, politically, populist leaders threaten liberal democracy by thwarting government functions, resulting in a populist backlash on an international scale. Besides that, the nativist rhetoric to appeal to "the people" is also typical of populism, leading to more aggressive, xenophobic international policies. Second, economically, populism poses a threat to global economy as populists not only are often antagonistic towards liberalized trade, disrupting economic growth both regionally and globally, but also strongly favor protectionist policies that benefit their own country at the expense of others. Third, populists pose threats to incumbent international institutions, raising the possibility of escalation of political conflicts into physical ones, undermining a liberal, multilateral international trade, and inhibiting global goals like protection of human rights or climate change that are important to all human beings. 
Populist leaders such as Boris Johnson and Donald Trump best exemplify the threat posed by populism, as they both distain liberal democratic procedures, and attempt to undermine both economic globalization and international institutions. Their tremendous influence on world politics as prominent political leaders of contemporary western countries shows how the populist threat is increasingly prevalent, threatening the liberal international order.

\section{Policy Recommendations}

This paper holds that populism is a threat to domestic and international politics, economic globalization, and international institutions promoting global cooperation. The policies below might be adopted to contain the contemporary spread of populist sentiment, redirecting the world to a more peaceful, liberal and cooperative path.

1) Fix issues leading to inertia and underrepresentation within democratic regime. Political reform is indispensable for containing populists and undermining their appeal to the public.

Current democratic regimes, like the British parliament, generates internal gridlocks and react inefficiently and hesitantly to urgent political issues, thereby allowing a populist leader to thwart the regular democratic processes, to effectuate his undeliberated policies and to increase his own popularity in the case of Brexit. By a parity of reasoning, the US Congress also produces gridlocks due to exorbitant partisanship and elite-domination. Existing political parties in the US are inadequate in responding to the voices of many electorates as well, resulting in the "representation gap" due to party polarization (Oliver \& Rahn, 2016). Underrepresented and frustrated, electorates thus resort to populism.

Policies should be enforced to improve the overall efficiency of the government and to make the people feel their power and influence on the regime. What's more, within parties, strict discipline and conformity of party members to the leader's agenda should also be appeased, if not appealed, in order to address the public content discontent when the officials that people elected obey to the party's orders rather than faithfully reflect their own interests.

2) Compensate for the industries hurt by trade globalization through redistribution within the state, so as to reduce the public appeal of populists.

The redistribution effects of globalized economy ail domestic industries, low-income workers and residents in rural regions, inducing their populist sentiments (Rodrik, 2018). To tackle this problem, the government should make amends to the industries and regions that suffer a great loss due to increased globalization. The aim is to raise taxes for the sectors that benefit the most such as finance and high-tech companies, and limit the number of potential freeloaders to the minimum. However, while increasing government expenditures on welfare states appears to be an ideal solution, it could induce an even stronger right-wing backlash. Thus, the government has to be extremely prudent in its decision to make compensation through redistribution policies, especially for 
the more libertarian-leaning US.

3) Re-balance integration of international community by rearranging the international organizations and agreements.

International institutions are the cornerstone of liberal international order (Ikenberry, 2018). However, populists harshly chastise them for their inefficiency, excessive extent of integration and mutual interdependence, as well as elitist corruption. Despite the blatant and melodramatic nature of their criticism, problems do exist in most incumbent international institutions.

For instance, the only directly elected body by EU citizens, European Parliament has no legislative powers until the issue of Lisbon Treaty 2007. The unsatisfying performance of EU over the Greek crisis and the 2008 crisis added momentum to populists. Worse, the EU has not effectively resolved the problem of democratic deficit yet. It is evident that, if EU were to secure its authority, or even integrity in the future, it should give more rights to the EU citizens to regain people's support from populist parties.

For "weakened" institutions such as WTO, it is even more urgent to restore the international community's faith for it. WTO law is in crisis partly due to its lack of "teeth", meaning that the institutions must be reformed to maintain its relevance in global economy. Reforming the appointment of Appellate Body members so that one hostile country cannot render it non-functioning would be a good place to start. WTO could also rely more on other great economic powers such as China, Japan and the EU, who would be willing to cooperate with the WTO in order to gain certain advantages.

In a nutshell, for institutions that seem to have been overreaching, they ought to return rights back to the people's hands; whereas for the institutions that are not sufficiently binding, it might be necessary to take initiatives to play a more active role in international governance.

\section{Conclusion}

The paper aims to demonstrate that the rise of populism in the west has had a tremendous negative impact on the incumbent liberal democracies, the trend of economic globalization, as well as the global governance achieved and maintained by international organizations, proving itself a threat to international order. These populist threats can be observed in both North America and Europe, exemplified by populist leaders Boris Johnson and Donald Trump, with their attempts to challenge the foundation of liberal democracy and liberal international order.

By situating the analysis of populist threat regarding the liberal international order in a contemporary context, the paper provides insight into populist rise at the end of the second decade of the 21th century. The paper also focuses on the potential threats that populism may engender rather than the causes of populism, thus it fills a gap that existent literature often misses. Moreover, the paper offers policy recommendations in countering the beguiling rhetoric of populist politicians, and in reinforcing incumbent liberal democratic procedures as well 
as international institutions so as to foster healthy international cooperation rather than nativist hostility in international relations. A potential solution that the paper identifies, for instance, is to fix the existing defaults within the incumbent regime, improving its efficiency and empowering "the people". Another solution is to cope with the inevitable redistribution effect resulting from economic globalization, compensation ought to be made regarding industries that have suffered economic loss in the process of economic globalization. It is equally imperative to reform international institutions so as to reinforce their roles in international order as well, by giving more power to "the people" and individual member states within those international institutions.

\section{Acknowledgements}

We would like to express our sincere gratitude to professor Nuno Monteiro, who has offered us great help during the process, revising each draft with patience and offering constructive suggestions for further improvement. Had it not been for his insightful comments and professional academic opinions, this article would not have been possible.

We are also grateful to CIS project. Without it, we would not have received the precious opportunity to work under the guidance of a prominent scholar in the field of international relations.

\section{Conflicts of Interest}

The authors declare no conflicts of interest regarding the publication of this paper.

\section{References}

Brubaker, R. (2017). Why Populism. Theory \& Society, 46, 357-385. https://doi.org/10.1007/s11186-017-9301-7

Gimson, A. (2015). Boris: The Rise of Boris Johnson (pp. 35-36). Newick: Read How You Want.

Ikenberry, J. (2018). The End of Liberal International Order. International Affairs, 94, 7-23. https://doi.org/10.1093/ia/iix241

Moffitt, B. (2015). How to Perform Crisis: A Model for Understanding the Key Role of Crisis in Contemporary Populism. Government and Opposition, 50, 89-217. https://doi.org/10.1017/gov.2014.13

Müller, J. W. (2016). What Is Populism? (pp. 64-66). Philadelphia: Univeristy of Pennslyvania Press. https://doi.org/10.9783/9780812293784

Norris, P., \& Ingleheart, R. (2016). Trump, Brexit, and the Rise of Populism: Economic Have-Nots and Cultural Backlash. SSRN Electronic Journal, RWP16-026, 1-53. https://doi.org/10.2139/ssrn.2818659

Oliver, J. E., \& Rahn, W. M. (2016). Rise of the Trumpenvolk: Populism in the 2016 Election. The Annals of the American Academy of Political and Social Science, 667, 189-206. https://doi.org/10.1177/0002716216662639

Penny, T., \& Hutton, R. (2019). May Faces Worst Government Defeat in 95 Years in Brexit Vote. 
https://www.bloomberg.com/news/articles/2019-01-14/may-faces-worst-government-d efeat-in-95-years-in-key-brexit-vote

Rodrik, D. (2018). Populism and the Economics of Globalization. Journal of International Business Policy, 1, 12-33. https://doi.org/10.1057/s42214-018-0001-4

Taggart, P. (2004). Populism and Representative Politics in Contemporary Europe. Journal of Political Ideologies, 9, 269-288. https://doi.org/10.1080/1356931042000263528

Toynbee, P. (2020). Why Is Boris Johnson Waging War on the EU? To Distract from His Cuts.

https://www.theguardian.com/commentisfree/2020/feb/03/boris-johnson-eu-cuts-brexi t-damage 